\title{
COENOLOGICAL DATA ON TEMPERATE SEMIDESERT SANDY GRASSLANDS IN HUNGARY
}

\author{
G. KEMÉNY, K. PENKSZA, Z. NAGY and Z. TUBA \\ Dept Botany and Plant Physiology, Fac. Agricult. Environm. Sci. \\ Szent István University of Gödöllő, H-2103 Gödöllő, Páter Károly út 1, Hungary; \\ E-mail:kazmerka@drotposta.hu
}

(Received 10 December, 2000)

\begin{abstract}
A neighbouring-quadrate transect study was conducted in order to examine the possible relationship between small scale topography and coenotaxa occurrence and cover in subassociations of Festucetum vaginatae Rapaics ex Soó 1929 sandy grassland plant community near Fülöpháza. These investigations served as a starting point in later soil seed bank studies. Cover of species was recorded in three transects of different exposition starting on the top of different dunes and ending in the depressions.

Subassociations and facies forming species of the community occurred in all investigated transects. Parts of the transects could not have been classified unambiguously into any of the coenotaxa mentioned in the literature. In these zones the characteristic species of the different subassociations and facies were occurring together. These patches are probably also the ones where changes in dominance relations and simultaneous spread of a species can relatively easily happen, as it is the case with Cleistogenes serotina. Annual vegetation of the open sandy grassland, on the other hand, has occurred only in the transition zones, between the subassociations or facies. In these transects moss-lichen synusia were present usually in the subassociation Festucetum vaginatae stipetosum pennataeKerner 1863.
\end{abstract}

Key words: Festucetum vaginatae Rapaics ex Soó 1929, association, sandy grassland, subassociations and facies forming species

\section{INTRODUCTION}

The Festucetum vaginatae Rapaics ex Soó 1929 (Borhidi 1996) grassland is widely distributed throughout the Danube Basin and as a "paraclimax" community it develops on loose calcareous sandy soils. This perennial grassland shows some semidesert characteristics for edaphic reasons. Variation in species composition is apparently linked to small-scale topographical diversity of this area.

First coenological records of the community have been published by Rapaics (1923) with emphasis placed on the introduction of the HultSernander method for estimating cover values, rather than on the description of the community, subsequently referred to by Soó (1929), who di- 
vided the Festuca vaginata association into vicariant types of danubiale, tibescense and deliblaticum, presenting the table of the coenological records and the A-D and $K$ values.

In later works possible successional series have also been dealt with (Magyar 1933, Hargitai 1940, Zsolt 1943, Pócs 1954, Zólyomi 1958, Fekete 1992). A successional scheme concerning the whole xeroseries on the neighbouring sandy areas is suggested by Hargitai (1940). The Festucetum vaginatae danubiale community was considered diverse in its development too, therefore several subassociations and within them more facies have been distinguished. Magyar (1933) has described four subassociations acknowledged in most of the works published in this topic later, although as much as ten different subassociations have also been reported (Soó 1964). A detailed description of the species composition is presented by Kárpáti and Kárpáti (1954), and Fekete et al. (1976). Additional important information on the local vegetation is presented by Szodfridt (1969).

Features arising from the mosaic composition of the vegetation on the sand dunes and the stressful environment have inspired studies of different aspects, too. Surveys have been conducted on the photosynthetic activity (Fekete and Tuba 1982) and reproductive allocation (Fekete and Melkó 1981, Fekete et al. 1988) in the species of the Festucetum vaginatae danubiale community at different successional stages. Invasion of the grassland by Cleistogenes serotina has been studied by Bagi $(1996,1997)$.

One possible method to test the assumed relationship between particular microtopographical features and the occurrence of subassociations of the Festucetum vaginatae danubiale community is to record the species cover by using transects consisting of several adjacent quadrates and stretching over a distance enough to embody substantial variation in small scale topography of the area (e.g. along an incline). By this way, it is also possible to characterise the vegetation of the transition zones in the transects lying between the subassociations, or equally, to verify the existence of sharp boundaries of these assemblages. This approach also provides the opportunity to investigate, whether the occurrence of moss and lichen synusia is linked to a particular coenotaxon or rather, are related to the small-scale morphological variation of the surface. Further aim of the present work was also to report the actual coenological records on the open sandy grassland subassociations around the Fehér-hegy. This study served as a starting point in a subsequent soil seed bank survey. 


\section{MATERIALS AND METHODS}

The study area is situated ca $25 \mathrm{~km} \mathrm{~W}$ of Kecskemét in the Hungarian Great Plain (Kiskunság National Park, near Fülöpháza). The sand hills are covered by grasslands. The mean annual precipitation is about $450 \mathrm{~mm}$. The vegetation cover is maximum $50-60 \%$, and the total species number is low (40-50). As to geographical distribution and life form, the constituent species are mainly continental, Pontic, Ponto-Pannonian hemicryptophytes and therophytes, but some chamaephytes and geophytes also occur. A special feature is the presence of numerous endemic taxa characteristic of the habitat.

The investigated vegetational area covers the territory of our soil seed bank study. Soil seed bank sample areas have been selected in the Festucetum vaginatae danubiale (Soó 1929) 1933 community's subassociations and facies around the Fehér-hegy. Coenological recording has been made in adjacent $2 \mathrm{~m} \times 2 \mathrm{~m}$ quadrates giving transects (Whittaker 1956, 1967) stretching from the top of the different sand dunes to SE, NE and SW directions along the slopes and consisting of 36, 15 and 16 quadrates, respectively.

The first (SE) transect included subassociations Festucetum vaginatae festucetosum vaginatae Magyar 1933 and stipetosum pennatae Kerner 1863, and also the facies Poa bulbosa. The second (NE) transect included subassociations Festucetum vaginatae stipetosum pennatae Kerner 1863 and fumanetosum Magyar 1933 also the facies Poa bulbosa and Cleistogenes serotina. The third (SW) transect stretched along Euphorbia seguieriana and Koeleria glauca facies of the subassociation Festucetum vaginatae stipetosum pennatae Kerner 1863. Coenological data (percentage cover) have been recorded in 12 May and 30 September, 1993. The reported data presented in tables and cover graphs (Whittaker 1967, Krebb 1983, Penksza et al. 1994) are the sums from these two occasions.

Species names and life forms follow Simon (1992), community nomenclature was adapted from Soó $(1964)$. Borhidi's $(1993,1995)$ system was followed to identify social behaviour. Cluster analysis was carried out on presence-absence data (Euclidean distance) using the SYN-TAX package (Podani 1993). 
Table 1

Cover values (\%) and life forms for species occurring in the first transect (LF $=$ life form)

Quadrates in the first transect $\quad 1 \quad 2 \quad 2 \quad 3 \quad 4 \quad 5 \quad 6 \quad 7 \quad 8 \quad 9 \quad 101112131415161718192021222324252627282930313233343536$ Festuco-Brometea species

Asparagus officinalis

Bothriochloa ischaemum

Bromus mollis

rophila verna

Holosteum umbellatum

Linaria genistifolia

Medicago minima

Poa bulbosa

Scabiosa ochroleuca

Festucetalia vaginatae specie

Arenaria serpyllifolia

Bromus tectorum

uniperus communis

Festucion vaginatae specie

Alkanna tinctoria

Centaurea arenaria

Festuca vaginata

Koeleria glauca

Polygonum arenarium

Secale sylvestre

$\begin{array}{lllllllllll}3 & 1 & 1 & 1 & 1 & & 1 & 1 & 1 & 1 & 1 \\ & 1 & 1 & 1 & & & & & & & \end{array}$

510101015101010234

Stipa borysthenica

Stipa borysthenica

Tragopogon floccosus

$\begin{array}{llll} & 1 & 1 & 1 \\ 1 & 3 & 2 & 3\end{array}$

$\begin{array}{lllll}3 & 2 & & 2 & 2\end{array}$

$\begin{array}{llllllllllllllll}2 & 2 & 1 & 3 & 2 & 2 & 2 & 6 & 3 & 6 & 5 & 5 & 10 & 6 & 8 & 10 \\ & 5 & 6 & & 6 & 6 & 5 & 5 & 5 & 20 & 20 & 25 & 15 & 20 & 20 & 15\end{array}$

Kocies

$\begin{array}{lllllllllll} & & & & 2 & & & 2 & & 2 & 2 \\ 5 & 5 & 5 & 3 & 3 & 3 & 2 & 1 & & 1\end{array}$

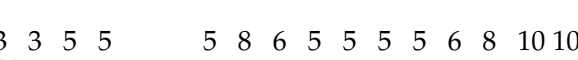

$\begin{array}{llll}1 & 5 & 10 & 10\end{array}$

52015201510202015152020152020201515101540352520251020155

$\begin{array}{lllllllllll}5 & 55 & 3 & 10158 & 5 & 5 & 5 & 10 & 5 & 5 & 4\end{array}$

13

21

$\begin{array}{llllll}3 & 3 & 5 & 8 & 5\end{array}$

$\begin{array}{llccccc}5 & 5 & 10151510201515158 & 2 & 152020 & 1 & 1 \\ 3 & & \end{array}$

3

3
3

$\begin{array}{llll}2 & 2 & 1 & 1\end{array}$

Alyssum tortuosum

$\begin{array}{llllll}3 & 1 & & \\ 1 & 3 & 3 & 3 & 3 & 3\end{array}$

.

$\begin{array}{lllllllll}1 & 4 & 3 & 3 & 5 & 3 & 2 & 2 & 2\end{array}$

$\begin{array}{lllll}5 & 5 & 5 & 5 & 105\end{array}$

55

36

Carex liparicarpos

Euphorbia seguierian

$\begin{array}{lllll}25105 & 155 & 5 & 5 & 3\end{array}$

53 
Table 1 (continued)

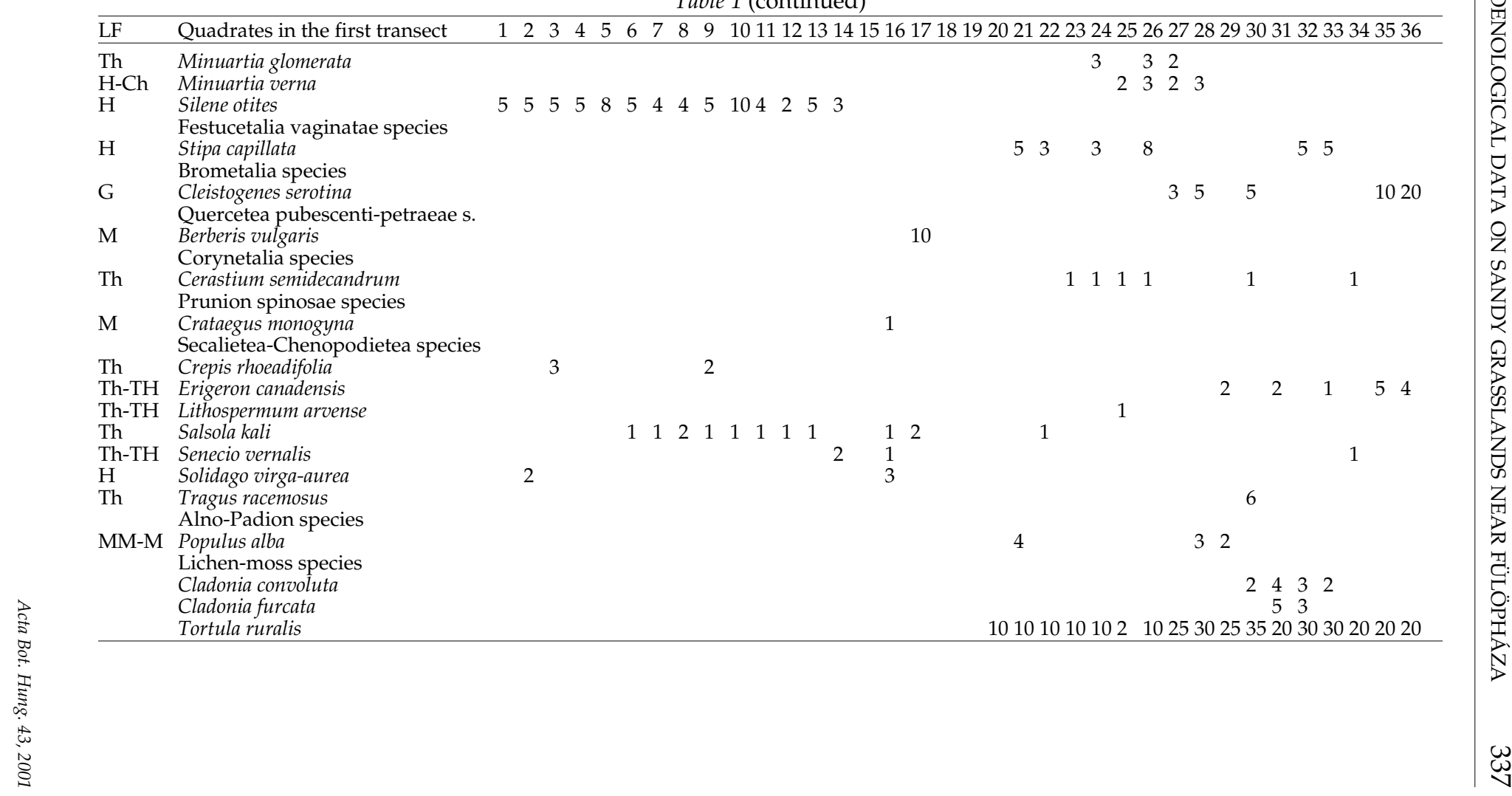




\section{RESULTS AND DISCUSSION}

\section{Characteristics of the vegetation in the transects}

Sample quadrates 1-20 of the first transect (Table 1) are characterised by species of the subassociation festucetosum vaginatae of the Festucetum vaginatae danubiale community. Cover values by Stipa borysthenica were as high as those by Festuca vaginata in quadrates 20-29. High cover values by Bothriochloa ischaemum considered as facies forming species here and as a separate subassociation elsewhere (Soó 1964) that caused difficulties in coenosystematic identification. Subassociation forming species (Stipa capillata, Fumana procumbens) and facies forming species like Cleistogenes serotina, Koeleria glauca were also present in this zone, while the next part of the transect (quadrates 30-39) clearly belonged to Festucetum vaginatae stipetosum pennatae, with the presence of the facies forming Poa bulbosa. Characteristic annual species of the open sandy grasslands (Bromus tectorum,

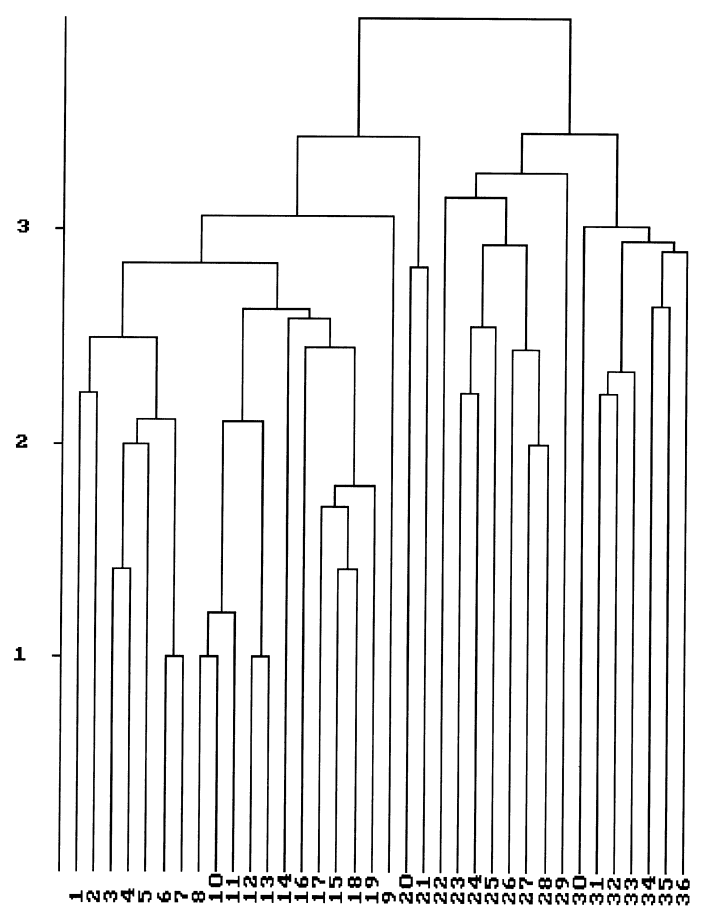

Fig. 1. Dendrogram of the cluster analysis carried out on species presence-absence data in the 1st transect. Quadrates in the transect are noted by numbers, the transect starting from the top of the dune 
Secale sylvestre) occurred on the top of the dune (qts 1-2) and in the transition zone (qts 15-20) between the first two zones. Occurrence of the moss and lichen synusia were typical from the twentieth quadrate downwards the slope. Separation of the three zones is illustrated by the dendrogram (Fig. 1).

Table 2

Cover values (\%) and life forms for species occurring in the second transect (LF $=$ life form)

\begin{tabular}{|c|c|c|c|c|c|c|c|c|c|c|c|c|c|c|c|}
\hline$\overline{\mathrm{LF}}$ & Quadrates in the second transect & 12 & 3 & 4 & 5 & 6 & 7 & 8 & 9 & & & & & & 15 \\
\hline & Festuco-Brometea species & & & & & & & & & & & & & & \\
\hline $\mathrm{H}$ & Bothriochloa ischaemum & & & & & & & & & & 2 & 3 & & & \\
\hline Th & Erophila verna & & & & & & 2 & & & & & & & & \\
\hline Th & Holosteum umbellatum & 12 & 2 & 2 & & & & & 1 & 2 & 3 & 4 & 3 & & \\
\hline Th-TH & Medicago lupulina & & & & & & 4 & & & & & & & & \\
\hline Th & Medicago minima & & & & & & & 5 & 5 & 5 & 2 & & & & \\
\hline $\mathrm{H}$ & Poa bulbosa & & 4 & 6 & 8 & 1 & 1 & 2 & 2 & 25 & & 5 & & & \\
\hline Th & Saxifraga tridactylites & & & & & 2 & 1 & 5 & 5 & 5 & 5 & 5 & & & \\
\hline $\mathrm{H}$ & $\begin{array}{l}\text { Scabiosa ochroleuca } \\
\text { Festucetalia vaginatae species }\end{array}$ & & & & & & & & & & & & & & 2 \\
\hline Th & Arenaria serpyllifolia & 11 & 1 & 1 & 1 & 8 & 8 & 1 & 1 & 1 & 1 & 1 & 1 & 8 & 1 \\
\hline $\mathrm{H}$ & $\begin{array}{l}\text { Helichrysum arenarium } \\
\text { Festucion vaginatae species }\end{array}$ & & & & & & & & & 8 & 7 & 5 & & 2 & \\
\hline $\mathrm{H}$ & Alkanna tinctoria & & & 4 & 4 & 4 & & & & & & & & & \\
\hline $\mathrm{H}$ & Astragalus varius & & & & & & & 5 & & & & & & & \\
\hline $\mathrm{H}$ & Festuca vaginata & 55 & 5 & & & 3 & 2 & & & & & 3 & 4 & & \\
\hline $\mathrm{G}(\mathrm{Ch})$ & Gypsophila fastigiata & 35 & 5 & & & & & & & & & & & & \\
\hline $\mathrm{H}$ & Koeleria glauca & 6 & & & 4 & & & & & & & 1 & 6 & 4 & 4 \\
\hline Th & Silene conica & 1 & & & & & & & 2 & & & 1 & 5 & & \\
\hline $\mathrm{H}$ & Stipa borysthenica & 115 & 2 & 15 & 3 & 3 & 3 & 1 & 15 & 2 & & 35 & 25 & & 35 \\
\hline $\mathrm{H}$ & Syrenia cana & 11 & 1 & 1 & & & & & & & 4 & & & & \\
\hline & Brometum tectorum species & & & & & & & & & & & & & & \\
\hline Th & Kochia laniflora & 12 & 1 & 1 & 1 & 1 & & & 1 & & & & & & \\
\hline $\mathrm{Ch}$ & $\begin{array}{l}\text { Festucion valesiacae-vaginatae s. } \\
\text { Alyssum tortuosum }\end{array}$ & 3 & 2 & & & & & & & & & & & & \\
\hline $\mathrm{N}$ & Fumana procumbens & 325 & 2 & 25 & 15 & 5 & 8 & & & & & 5 & 8 & & 15 \\
\hline & Festucetalia valesiacae-vaginatae s & & & & & & & & & & & & & & \\
\hline Th & Bromus squarrosus & & & & & & 1 & & & & & & & & \\
\hline & Carex liparicarpos & 2 & 8 & 8 & 4 & 2 & 2 & & & & & & & & \\
\hline $\mathrm{H}-\mathrm{Ch}$ & $\begin{array}{l}\text { Minuartia verna } \\
\text { Brometalia species }\end{array}$ & & 2 & 2 & 2 & & & & & & & & & & \\
\hline G & $\begin{array}{l}\text { Cleistogenes serotina } \\
\text { Corynetalia species }\end{array}$ & & & 5 & 2 & 8 & 5 & 15 & 15 & 1 & & & 2 & & \\
\hline Th & $\begin{array}{l}\text { Cerastium semidecandrum } \\
\text { Secalietea-Chenopodietea species }\end{array}$ & 1 & 1 & 2 & 2 & 4 & 5 & 5 & 5 & 5 & 5 & 8 & 8 & 8 & 1 \\
\hline Th & Crepis rhoeadifolia & & & & & & & & & 3 & 3 & & & & \\
\hline Th & Erigeron canadensis & & & & & & & & & & & & & 1 & 2 \\
\hline Th-TH & Lithospermum arvense & & & & & 1 & 1 & & & & & 2 & 2 & & \\
\hline Th-TH & Senecio vernalis & 1 & & & & & & & & 1 & & & & & 1 \\
\hline & Lichen-moss species & & & & & & & & & & & & & & \\
\hline & Cladonia c & 22 & & 3 & 3 & 2 & 4 & 3 & 1 & 5 & 5 & 2 & & & \\
\hline & Clado & 1 & 4 & & & & & & & & & & & & \\
\hline & Tortula ruralis & & 1 & & & & 5 & 5 & 5 & 8 & & 1 & 1 & 4 & 8 \\
\hline
\end{tabular}




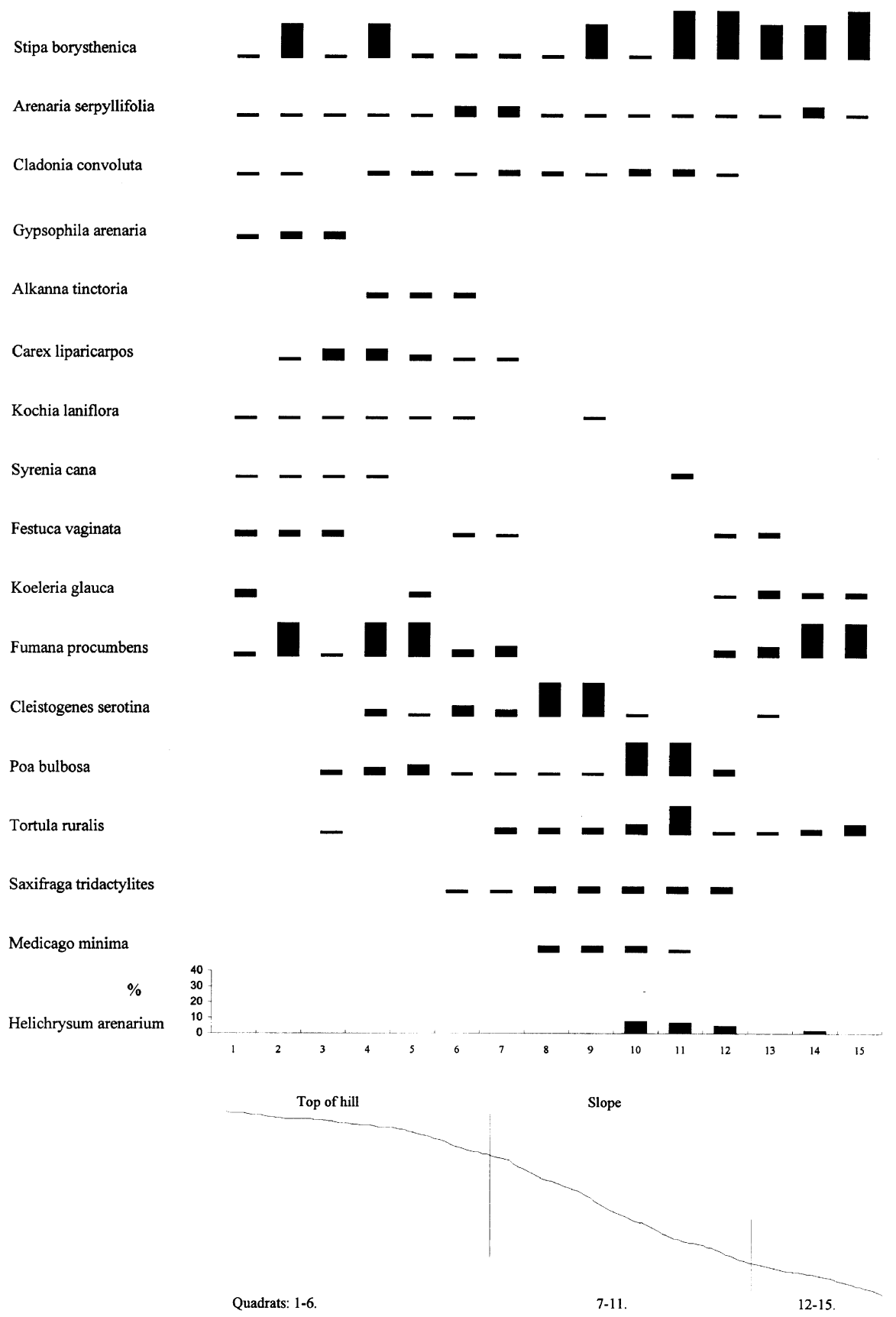

Fig. 2. Cover changes for selected species along the 2 nd transect starting from the top (1st qt) of the sand dune 


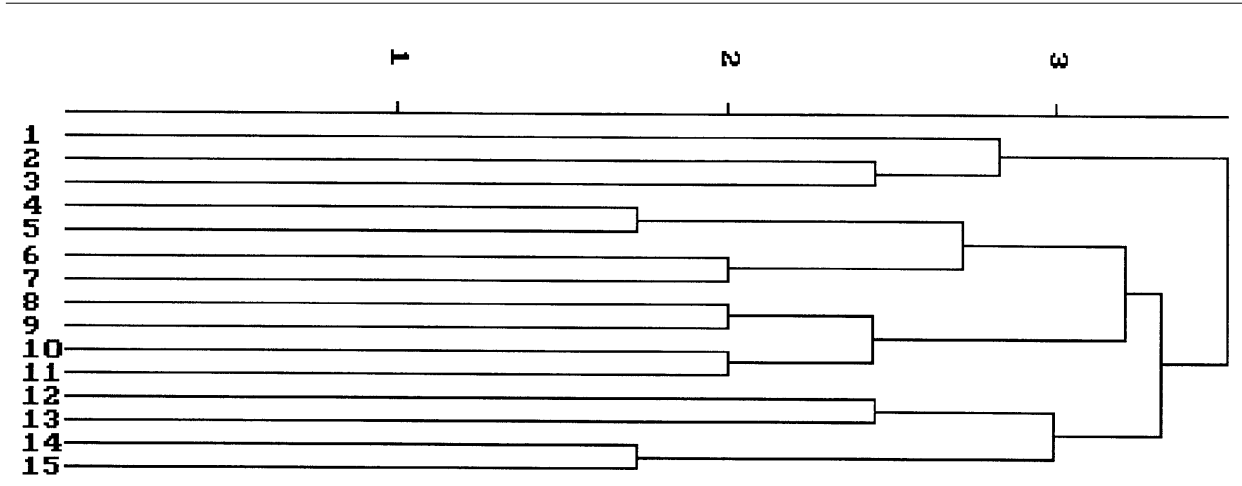

Fig. 3. Dendrogram of the cluster analysis carried out on species presence-absence data in the 2nd transect. Quadrates in the transect are noted by numbers, the transect starting from the top of the dune

Vegetation of the second transect comprised up from subassociations of the Festucetum vaginatae stipetosum pennatae and fumanetosum (Table 2, Fig. 2). On the top and in the bottom of the slope both species were present (qts 1-7 and 11-15, respectively), while Fumana procumbens was lacking from the middle transition zone (qts 8-11) where significant cover by Cleistogenes serotina and Poa bulbosa was recorded concurrently with the presence of Helichrysum arenarium, Saxifraga tridactylites, Medicago minima, and the moss species Tortula ruralis. Annual species of the open sandy grassland were not present, a fact that may be explained by the high cover of perennials although occurrence of the main species (Festuca vaginata) of the community was rather rare here. Quadrates containing Festuca vaginata (qts 1-3, 6-7 and 12-13) have separated from the remaining ones (Fig. 3) consisting of the Poa bulbosa (qts 10-11) and Cleistogenes serotina (qts 8-9) facies of the stipetosum pennatae subassociation.

Stipa borysthenica was present along the whole length of the third transect (Table 3, Fig. 4), hence this area was identified as Festucetum vaginatae stipetosum pennatae subassociation. Out of the subassociation forming species, Fumana procumbens and Festuca vaginata were present together with Stipa borysthenica, while out of the facies forming ones Euphorbia seguieriana (qts 1-9) and Koeleria glauca (qts 11-16) were found. Annual species were present between the two facies zones, moss-lichen synusia were present from qt. 9 to the end of the transect at the bottom of the slope. The two coenotaxa were separated from each other and the transition zone between the middle and the bottom of the slope (qts 9-10) also gave a distinct group (Fig. 5). 
Table 3

Cover values (\%) and life forms for species occurring in the third transect $(\mathrm{LF}=$ life form)

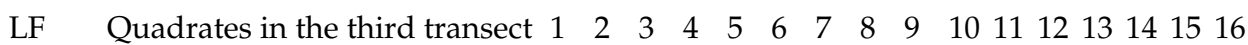

Festuco-Brometea species

Th-TH Alyssum alyssoides

Th Erophila verna

Th Holosteum umbellatum

$\mathrm{H} \quad$ Linaria genistifolia

Th Medicago minima

$\mathrm{H} \quad$ Poa bulbosa

Festucetalia vaginatae species

Th Arenaria serpyllifolia

Th Bromus tectorum

Festucion vaginatae species

$\mathrm{H} \quad$ Astragalus varius

$\mathrm{H} \quad$ Festuca vaginata

$\mathrm{H} \quad$ Koeleria glauca

Th Polygonum arenarium

Th Secale sylvestre

Th Silene conica

$\mathrm{H} \quad$ Stipa borysthenica

$\mathrm{H}$ Syrenia cana

Th Tribulus terrestris

Brometum tectorum species

Th Kochia laniflora

Festucion valesiacae-vaginatae s.

Ch Alyssum tortuosum

$\mathrm{N} \quad$ Fumana procumbens

Festucetalia valesiacae-vaginatae s.

$\begin{array}{lllllllll}8 & 5 & 5 & 8 & 1 & 4 & & 2 & 5\end{array}$

$\begin{array}{llll}25 & 1 & 8 & 8\end{array}$

$\begin{array}{lll}3 & 2 & 2\end{array}$

$\begin{array}{lllllllll}2 & 2 & & & & 2 & & 5 & 5 \\ & & & & & & & & \\ & 1 & 3 & 5 & 5 & 5 & & & \\ & & & 5 & & & & \end{array}$

$\begin{array}{llllllllll}4 & 1 & 1 & 15 & 15 & 15 & 1 & 5 & 5 & 5\end{array}$

$\begin{array}{lllll}5 & 1 & 1 & 1 & 5\end{array}$

25

$\begin{array}{llllllll}3 & 4 & 5 & 4 & 5 & 5 & 5 & 3\end{array}$

$\begin{array}{lllllllllll}5 & 5 & 5 & 5 & 1 & 5 & 5 & 1 & 2 & 2 & 15\end{array}$

$\begin{array}{lllllll}8 & 1 & 1 & 15 & 1 & 8 & 8 \\ 1 & & 2 & 2 & 3 & & 3\end{array}$

$\begin{array}{lllll}5 & 5 & 5 & 4 & 3\end{array}$

Th Bromus squarrosus

G Carex liparicarpos

$\mathrm{H} \quad$ Chondrilla juncea

$\mathrm{H} \quad$ Euphorbia seguieriana

Th Minuartia glomerata

Th-TH Minuartia verna

$\mathrm{H} \quad$ Silene otites

Corynetalia species

Th Cerastium semidecandrum

Secalietea-Chenopodietea species

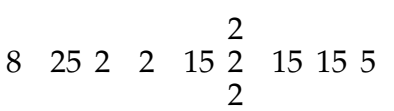

4
$5 \quad 1$

2
Crepis rhoeadifolia

Th Erigeron canadensis
Th-TH Lithospermum arvense

Th Salsola kali

Corynephoretalia species

Th Veronica dillenii

Th Veronica verna

Lichen-moss species

Cladonia convoluta

Cladonia furcata

Tortula ruralis

$$
\begin{array}{llllll}
4 & 5 & 2 & 4 & 2 & 2
\end{array}
$$

2

$24 \quad 45$

$\begin{array}{llll}4 & 2 & 2 & 2\end{array}$

$\begin{array}{lll}4 & 4 & 2\end{array}$

15

$\begin{array}{llllllll}4 & 4 & 5 & 5 & 5 & 5 & 5 & 5\end{array}$

$\begin{array}{lllllll}3 & 4 & 5 & 5 & 2 & 3 & 5\end{array}$

$\begin{array}{llllllll}5 & 15 & 1 & 3 & 5 & 4 & 4 & 5\end{array}$ 


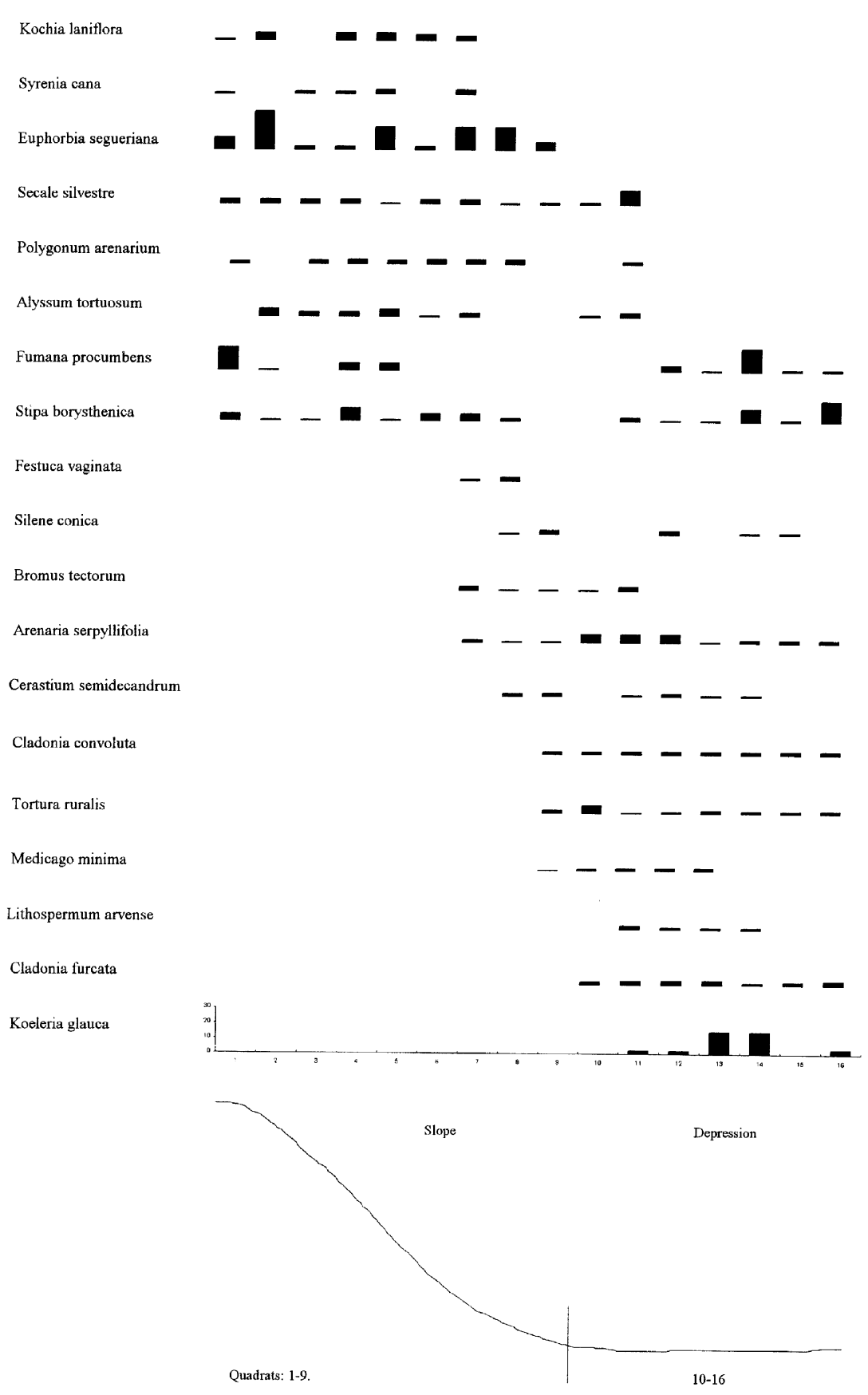

Fig. 4. Cover changes for selected species along the 3 rd transect starting from the top (1st qt) of the sand dune 


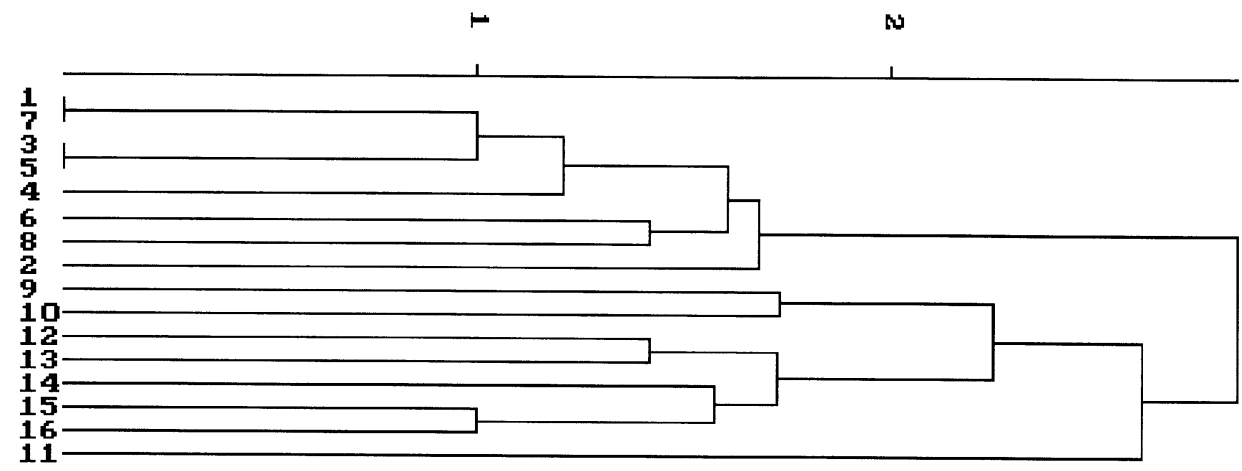

Fig. 5. Dendrogram of the cluster analysis carried out on species presence-absence data in the 3rd transect. Quadrates in the transect are noted by numbers, the transect starting from the top of the dune

A

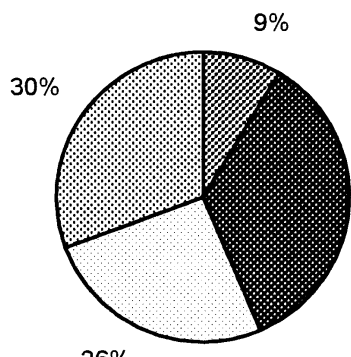

$26 \%$

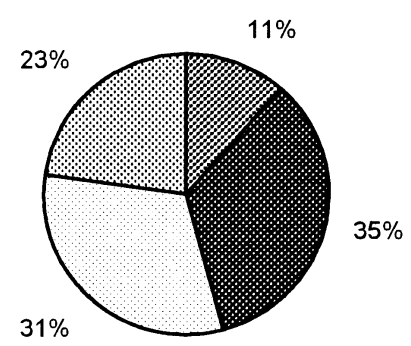

田

ST

C

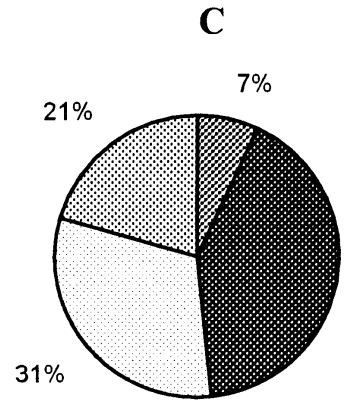

ㅁ. DT, W

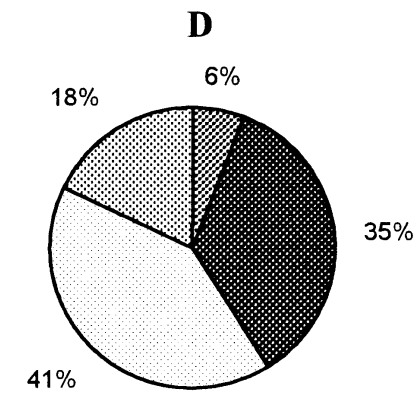

Fig. 6. Proportions of the species falling into different social behaviour types (after Borhidi 1993, 1995). A: 1st transect: Festucetum vaginatae festucetosum vaginatae subassociation. B: 1st transect: Festucetum vaginatae stipetosum pennatae subassociation. C: 2nd transect: Festucetum vaginatae stipetosum pennatae subassociation. D: 3rd transect: Festucetum vaginatae stipetosum pennatae subassociation. Explanation: $\mathrm{C}=$ competitors, $\mathrm{ST}=$ stress tolerant, $\mathrm{NP}=$ natural pioneers, $\mathrm{DT}=$ disturbance tolerants, $\mathrm{W}=$ weeds 


\section{Coenogroups and social behaviour}

Most of the species found in the three transects belong to similar coenogroups (Tables 1-3), except for the members of the Festucion vaginatae association group, where grouping occurred according to subassociations. Cover of species belonging to the Festuco-Brometea grasslands is rather small on the top of the dunes, while their cover is increasing downwards along the transect together with that of Cleistogenes serotina. These zones may be considered as more degraded ones, although the presence of subassociation and facies forming species are also characteristic here.

Majority (70-80\%) of the species are characteristic of this habitat (Fig. 6). Ratio of competitors was the lowest in all coenogroups, while stress tolerants and natural pioneers received similar ratings. In Euphorbia seguieriana and Koeleria glauca facies of the Festucetum vaginatae stipetosum pennatae subassociation occupying warmest (SW) slope the share of natural pioneers was higher than that by stress tolerants. A smaller (20-30\%) ratio of the species belonged to the disturbance tolerants and weeds of disturbed habitats.

\section{Life form distributions along the transects}

In all subassociations the number of perennial and annual species were nearly the same. The cover was higher for the perennial than for the annual species (Fig. 7).

\section{CONCLUSIONS}

In accordance with the literature (Magyar 1933, Hargitai 1940, Zsolt 1943, Pócs 1954, Zólyomi 1958), present study shows subassociations and facies forming species of the community to occur in all investigated transects. Patches formed according to the dominance structure may correspond to the subassociations and facies mentioned in the literature. Significant part of the quadrates could not have been classified into either of the coenotaxa mentioned in the literature. In these zones the characteristic species of the different subassociations and facies are occurring together.

These patches are probably also the ones where changes in dominance relations and simultaneous spread of a species can relatively easily hap- 

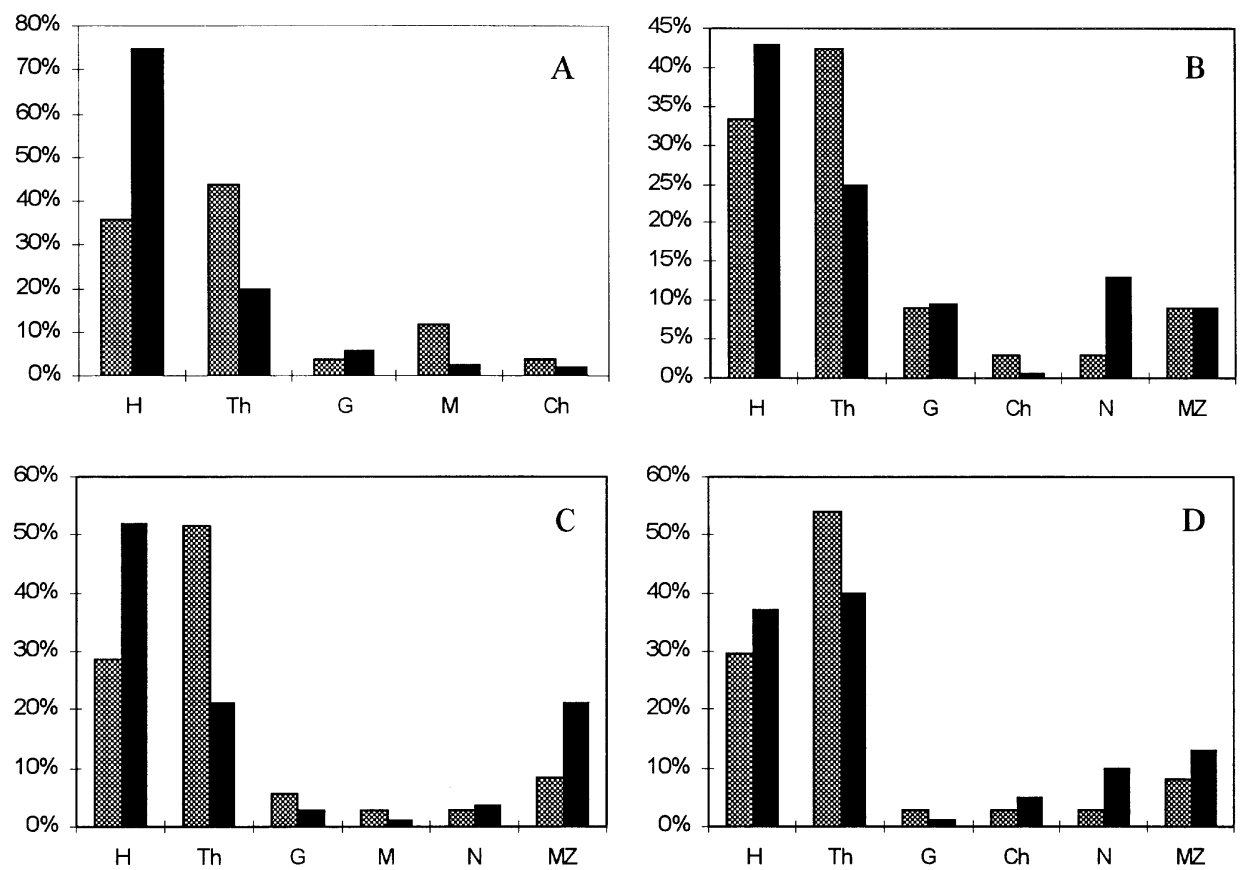

Fig. 7. Life form distributions and cover in the different subassociations. The first column shows the ratio of the species number (\%), the second column shows the cover values of species (\%). A: 1st transect: Festucetum vaginatae festucetosum vaginatae subassociation. B: 1st transect: Festucetum vaginatae stipetosum pennatae subassociation. C: 2nd transect: Festucetum vaginatae stipetosum pennatae subassociation. D: 3 rd transect: Festucetum vaginatae stipetosum pennatae subassociation

pen, as it is the case with Cleistogenes serotina. Relation between small-scale topography and occurrence of any of the subassociations is at least ambiguous.

Annual vegetation of the open sandy grassland, on the other hand, has occurred only in the transition zones, between the subassociations or facies. In these transects moss-lichen synusia were present usually in the subassociation Festucetum vaginatae stipetosum pennatae.

Acknowledgements - The authors wish to thank Prof. Gábor Fekete for revising the manuscript. This work was supported by the following grants: Hungarian Scientific Research Fund (OTKA F013226, 1545), ECOCRAFT (EU), MEGARICH(EU) and FKFP 472/97. 


\section{REFERENCES}

Bagi, I. (1996): A JATE Növénytani Tanszéke cönológiai és botanikai kutatásai a Kiskunsági Nemzeti Parkban 1994-1995. (Phytocenological and botanical researches of the Department of Botany of the A. J. University in the Kiskunság National Park, 1994-1995). In: Tóth, K. (ed.): 20 éves a Kiskunsági Nemzeti Park 1975-1995. Házinyomda Kft, Kecskemét, pp. 133-144.

Bagi, I. (1997): Átalakuló homoki vegetáció a Duna-Tisza közén. (Sandy vegetation in progress in the Kiskunság region). - Kitaibelia 2(2): 253-264.

Borhidi, A. (1993): A magyar flóra szociális magatartásformái. (Social behaviour types of the Hungarian flora). - A KTM Term. Hiv. és a JPTE Kiadványa, Pécs.

Borhidi, A. (1995): Social behaviour types, the naturalness and relative ecological indicator values of the higher plants in the Hungarian Flora. - Acta bot. hung. 39: 97-181.

Borhidi, A. (1996): An annotated checklist of the Hungarian plant communities, I. The non-forest vegetation. - In: Borhidi, A. (ed.): Critical revision of the Hungarian plant communities. Janus Pannonius University, Pécs, pp. 43-94.

Fekete, G. (1992): The holistic view of succession reconsidered. - Coenoses 7(1): 21-29.

Fekete, G. and Melkó, E. (1981): Reproductive allocation in the stages of sandy succession. Acta bot. hung. 27: 351-364.

Fekete, G. and Tuba, Z. (1982): Photosynthetic activity in the stages of sandy succession. Acta bot. hung. 28: 291-296.

Fekete, G., Tuba, Z. and Melkó, E. (1988): Background processes at the population level during succession in grasslands on sand. - Vegetatio 77: 33-41.

Fekete, G., Précsényi, I., Molnár, E. and Melkó, E. (1976): Niche studies on some plant species of a grassland community I. - Acta bot. hung. 22: 321-354.

Hargitai, Z. (1940): Nagykőrös növényvilága II. A homoki növényszövetkezetek. (Plant life in Nagykőrös II. The plant communities on sand). - Bot. Közlem. 37: 205-240.

Kárpáti, I. and Kárpáti, V. (1954): The aspects of the calciphilous turf (Festucetum vaginatae danubiale) in the environs of Vácrátót in 1952. - Acta bot. hung. 1: 129-157.

Krebb, K. (1983): Vegetationskunde. - Verlag Eugen Ulmer, Stuttgart.

Magyar, P. (1933): A homokfásítás és növényszociológiai alapjai. (Afforestation on sand and its phytosociological basis). - Erdészeti Kísérletek 35: 139-199.

Penksza, K., Barczi, A., Benyovszky, B. M., Möseler, V. M., Birkenheuer, V. and Szabó, T. (1994): Relationship between vegetation and soil on the northeastern slope of the Fehér-szirt (White cliff) of Kesztölc. - Tiscia 29: 3-10.

Podani, J. (1993): SYN-TAX 5.0: Computer programs for multivariate data analysis in ecology and systematics. - Abstracta Botanica 17: 289-302.

Pócs, T. (1954): A rákoskeresztúri “Akadémiai erdő" vegetációja. (Die Vegetation der "Akademischen Wald" im Rákoskeresztúr). - Bot. Közlem. 45: 283-295.

Rapaics, R. (1923): A növények társulása. (The plant community.) - Term. Tud. Közl. 55: 329-335.

Simon, T. (1992): A magyarországi edényes flóra határozója. (Field guide to the Hungarian vascular flora). - Tankönyvkiadó, Budapest.

Soó, R. (1929): Die Vegetation und die Entstehung der ungarischen Puszta. - J. Ecol. 17: 329-350.

Soó, R. (1964): A magyar flóra és vegetáció rendszertani-növényföldrajzi kézikönyve I. (Taxonomic-phytogeographical manual of the Hungarian Flora and Vegetation I.). - Akadémiai Kiadó, Budapest. 
Szodfridt, I. (1969): Borókás-nyárasok Bugac környékén. (Juniper-poplar stands in the environs of Bugac). - Bot. Közlem. 56: 159-165.

Whittaker, R. H. (1956): Vegetation of the Great Smoky Mountains. - Ecol. Monogr. 26: 1-80.

Whittaker, R. H. (1967): Gradient analysis of vegetation. - Biol. Rev. 42: 207-264.

Zólyomi, B. (1958): Budapest és környékének természetes növénytakarója. (The natural vegetation of Budapest and its surroundings). - In: Pécsi, M. (ed.): Budapest természeti képe. - Akadémiai Kiadó, Budapest.

Zsolt, J. (1943): A Szent-Endrei sziget növénytakarója. (The vegetation of Szentendre Island). - Index Horti Bot. Univ. Budapest. 6: 3-19. 